Animal Reproduction Research Institute, EL-Haram, Giza, Egypt.

\title{
ROLE OF PSEUDOMONAS AERUGINOSA AND PASTEURELLA MULTOCIDA ON SEMEN CHARACTERISTICS OF RABBIT BUCKS AND THEIR PATHOLOGICAL EFFECTS
}

(With 2 Tables, One Plate and 5 Figures)

By

\section{S.A. SELIM; AMAL A.M. GHONEIM; KH.Z. DOKHAN and ROWIDA M. RIAD}

(Received at 18/9/2008)

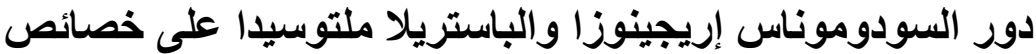

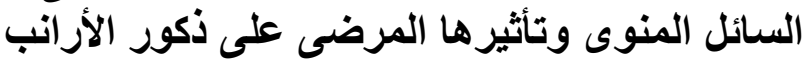

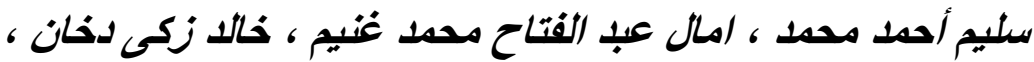

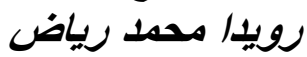

تم عزل ميكروب السودوموناس إريجينوز ا من غلفة للخصية و السودو موناس إريجينوزا

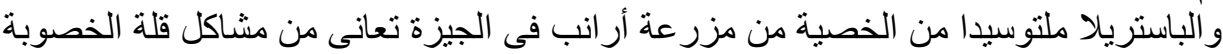

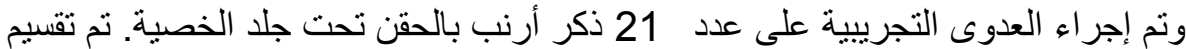

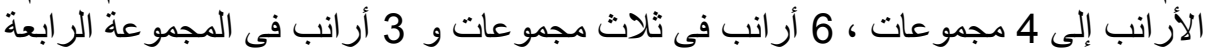

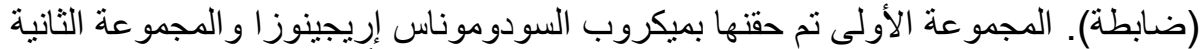

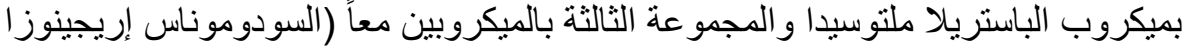

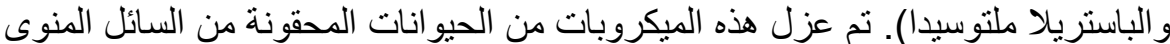

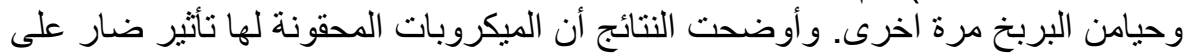

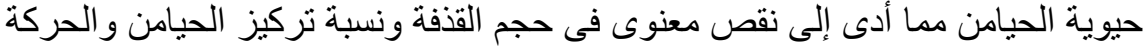

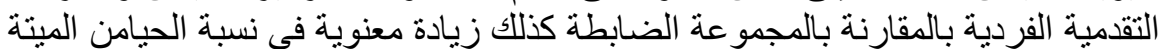

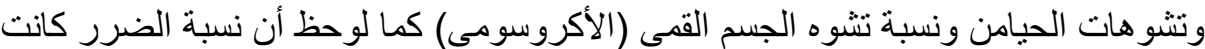

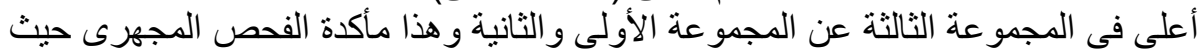

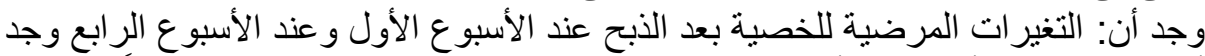

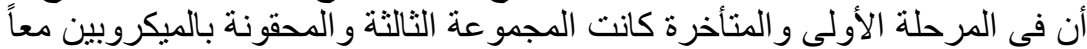

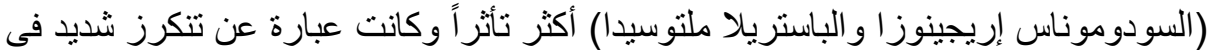

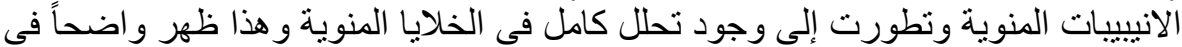

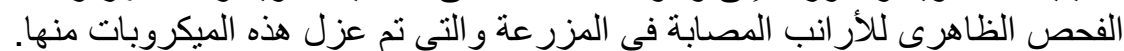

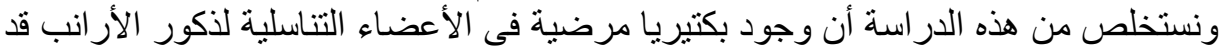
تؤدى إلى قلة الخصوبة وكذلك قد تنتقل هذه البكتيريا إلى الإناث. 
In this study experimental infection of mature rabbit bucks was carried out by the isolated bacteria from field cases. The gross and histopathological changes in testes in addition to semen characteristics were evaluated. Total twenty one rabbit bucks used in this experimental study were divided into 3 groups (6 in each), the groups, first, second \&third were inoculated subcutaneously(s/c) in scrotum with Pseudomonas aeruginosa, Pasteurella multocida and both Pseudomonas aeruginosa and Pasteurella multocida in order. The remaining 3 bucks were left as non infected control. Infection with Pasteurella and Pseudomonas had more deleterious effects than either Pasteurella or Pseudomonas alone on semen quality and testicular tissues. All affected groups had differed significantly from control; volume of semen $/ \mathrm{ml}$ was decreased significantly ( $\mathrm{p}<0.01$ ), concentration x $10^{6} / \mathrm{ml}$ of spermatozoa and percentage of motile sperm were decreased significantly ( $p<0.001$ ). Percentage of dead spermatozoa, major defects $\%$, minor defects $\%$ and acrosomal defects (semen) were increased significantly ( $\mathrm{p}<0.001)$. Also the acrosomal defect from epididymis was increased significantly ( $<$ 0.01). The third group was severly affected than first and second groups. The infected rabbit bucks with Pseudomonas aeruginosa and Pasteurella multocida either single or both resulted in moderate to severe gross scrotal inflammation, which lead to damage of the testicular parenchyma with different degrees of severity. Histopathological examination revealed less intense lesions in bucks infected with Pseudomonas aeruginosa compared with those infected with Pasteurella multocida or both organisms, in which the semeniferous tubules showed excessive necrosis and progressive to complete depletion of spermatogoneal cells.

Key words: Pseudomonas aeruginosa, Pasteurella multocida, semen, rabbit bucks.

\section{INTRODUCTION}

Reproductive efficiency is the most important economic factor in livestock production. Economically the fertility of male rabbit is of greater importance because the sperm is responsible for fertilizing the ova (AbdEL-Ghaffar, 1992). Infertility in rabbits represents one of the major problems that threaten rabbit reproduction and production. Female rabbit infertility have been studied as causes of this problem. However, no attention has been drawn to the possible role that might be played by rabbit bucks in this problem. Traumatic wounds cabable to transmit 
certain pathogens like Pasteurella multocida (Richardson, 2000), E.coli, Pseudomonas and Staphylococcus species (Rowida, 2000).

Pasteurella multocida is highly pathogenic for rabbits and therefore might be a cause of considerable economic losses in commercial rabbit production (Jaglic et al., 2008). Bacteria may get into semen and reduce its viability or kill the spermatozoa (Evans and Maxwell, 1987). So, this study was planned to determine the effect of some bacterial agents on the fertility of rabbit bucks by:

1- Isolation and identification of microorganisms from the testes and prepuce of infected rabbit bucks in field.

2- Experimental infection of healthy and normal fertile rabbit bucks by the isolated bacteria and re-isolation of the organisms from testes and semen of the inoculated rabbits.

3- Evaluation of semen and cauda epididymal sperm from normal and infected bucks.

4- Determination of the gross and histopathological changes in testes of experimentally infected rabbit bucks.

\section{MATERIALS and METHODS}

\section{Isolation and identification of the causative agent from field cases of rabbit bucks:}

Bacteriological samples was taken aseptically from buck testes showing necrotic lesion with severe orchitis and perform several infertile mating. The skin of affected testicle was cleaned and disinfected carefully with $70 \%$ ethyl alcohol (Cruickshank et al., 1975); then sterile needle syring was inserted in testes at border line between the necrotic part and the apparently healthy testicular part, followed by suction of part of testicular contents. After that the aspirated part was mixed with sterile nutrient broth. Swabs were taken from the prepuce of the infected infertile rabbit bucks. The samples were inoculated into nutrient broth and incubated at $37^{\circ} \mathrm{C}$ for $24 \mathrm{hrs}$, then loopfuls were streaked onto blood agar and MacConkey agar plates. The plates were incubated at $37^{\circ} \mathrm{C}$ for 24-48 hrs. Isolation and identification of the bacteria were done according to Finegold and Baron (1986).

For experimental infection, the inoculums of the isolated bacteria were prepared according to Nada (1994) for Pasteurella multocida $\left(10^{8}\right)$ viable organisms $/ \mathrm{ml}$, and Riad (2000) for Pseudomonas aeruginosa $\left(2.5 \times 10^{7} / \mathrm{ml}\right)$ viable organisms. The bacteriological examination was carried out after slaughtering of the inoculated rabbits on tests and semen. 


\section{Experimental animals:}

Total twenty-one rabbit bucks, aging from 10-12 months were reared in isolated cages and fed on unmedicated commercial balanced ration. Eighteen of the rabbit bucks used in experimental infection, were divided into 3 group (6 in each), the first group was inoculated subcutaneously $(\mathrm{s} / \mathrm{c})$ with $0.5 \mathrm{ml}$ of prepared culture of Pseudomonas aeruginosa in the left side of scrotum, the second group was inoculated s/c with $0.5 \mathrm{ml}$ of Pasteurella multocida in the left side of scrotum. The third group was inoculated $\mathrm{s} / \mathrm{c}$ with $1.0 \mathrm{ml}$ of culture of both Pseudomonas aeruginosa and Pasteurella multocida with similar dose in the left side of scrotum. While, the right sides of these groups were inoculated with $0.5 \mathrm{ml}$ sterile saline. At $1^{\text {st }}$ week post inoculation (P.I), 3 out of each group were sacrificed and the other 3 bucks of each groups were kept till the end of the experimental period ( $4^{\text {th }}$ week). The remaining 3 bucks were kept without inoculation as control.

\section{Semen collection:}

Semen was collected twice weekly for three weeks before inoculation using an artificial vagina according to the method described by Evans and Maxwell (1987) which proved to be normal semen characteristic (initial progressive motility not less than 70\%). After inoculation, semen samples were collected from bucks during the period of experiment with the same rate. After scarification of the bucks, semen were collected from cauda epididymis and were diluted (1:1) immediately with warmed $(37 \circ \mathrm{C}) 0.9 \% \mathrm{NaCl}$ for evaluation according to Reynolds et al. (1989). Immediately after semen collection by artificial vagina from live bucks and from cauda epididymal sperms from sacrificed bucks, Samples were individually evaluated as follows: volume $/ \mathrm{ml}$, concentration of spermatozoa $\mathrm{x} 10 \% \mathrm{ml}$ of sperm by using haemocytometre, percentage of sperm motility, percentage of dead spermatozoa, major and minor defects by using Eosin- Nigrosin stain (Blom, 1977) and acrosomal defects according to Evans and Maxwell (1987).

Cauda epididymal sperms of the experimentally infectd testis were compared with right, saline inoculated testis, Cauda epididymal sperms while semen values were compared with the values of same animals before the experimental infection.

\section{Pathological examination:}


The gross pathological findings were recorded in all bucks during the period of experiment. After scarification, Tissue specimens of the bucks testes and epididymis were collected, then fixed in the available fixative $10 \%$ formol saline (Riad, 2000), processed by conventional paraffin embedding technique, sectioned (3-4 $\mu \mathrm{m})$ and stained by hematoxylin and eosin (Bancroft and Stevens, 1990) for light microscopical histopathological examination.

\section{Statistical analysis:}

Data were statistically analyzed by using analysis of variance according to Snedecor and Cochran (1982) and the general model program of SAS (1990).

\section{RESULTS}

\section{Semen evaluation:}

Table 1: Influence of Pseudomonas aeruginosa and Pasteurella multocida on left epididyamal sperm at $1^{\text {st }}$ week post infection (Mean \pm S.R.):

\begin{tabular}{|l|c|c|c|c|}
\hline & Control $^{*}$ & $1^{\text {st }}$ Group & $2^{\text {sec }}$ Group & $3^{\text {rd }}$ Group \\
\hline Motility \% & $80 \pm 2.88^{\mathrm{a}}$ & $60 \pm 2.88^{\mathrm{b}}$ & $50 \pm 2.88^{\mathrm{c}}$ & $5 \pm 2.88^{\mathrm{d}}$ \\
\hline Dead \% & $8 \pm 1.15^{\mathrm{c}}$ & $74 \pm 1.15^{\mathrm{b}}$ & $85 \pm 2.88^{\mathrm{a}}$ & $90 \pm 2.88^{\mathrm{a}}$ \\
\hline $\begin{array}{c}\text { Abnormality \% } \\
\begin{array}{c}\text { Major } \\
\text { Minor }\end{array}\end{array}$ & $3 \pm 0.58^{\mathrm{c}}$ & $19 \pm 1.15^{\mathrm{b}}$ & $20 \pm 1.15^{\mathrm{b}}$ & $25 \pm 1.73^{\mathrm{a}}$ \\
\cline { 2 - 5 } & $10 \pm 2.88^{\mathrm{c}}$ & $20 \pm 1.15^{\mathrm{b}}$ & $34 \pm 2.31^{\mathrm{a}}$ & $40 \pm 0.58^{\mathrm{a}}$ \\
\hline Acrosmal Defect & $3^{\mathrm{b}}$ & $12 \pm 3.5^{\mathrm{a}}$ & $17 \pm 1.15^{\mathrm{a}}$ & $19 \pm 1.73^{\mathrm{a}}$ \\
\hline
\end{tabular}

*Control is the values of the right side of testis.

Figures with different superscripts $a, b, c$ and $d$ within row are significantly different at least $\mathrm{p}<0.01$ highly significant and $\mathrm{p} .<0.001$ severly significant

Table 2: Influence of Pseudomonas aeruginosa and Pasteurella multocida on semen characteristics at $4^{\text {th }}$ week post infection (Mean \pm S.R.):

\begin{tabular}{|l|c|c|c|c|}
\hline & Control & $1^{\text {st }}$ Group & $2^{\text {sec }}$ Group & $3^{\text {rd }}$ Group \\
\hline Volume/ml & $0.8 \pm 0.06^{\mathrm{a}}$ & $0.5 \pm 0.12^{\mathrm{b}}$ & $0.3 \pm 0.06^{\mathrm{bc}}$ & $0.2 \pm 0^{\mathrm{c}}$ \\
\hline Concentration/ml & $273 \pm 1.73^{\mathrm{b}}$ & $196 \pm 0.58^{\mathrm{a}}$ & $82 \pm 1.58^{\mathrm{c}}$ & $48 \pm 1.15^{\mathrm{d}}$ \\
\hline Motility \% & $75 \pm 2.88^{\mathrm{a}}$ & $30 \pm 2.88^{\mathrm{b}}$ & $20 \pm 2.88^{\mathrm{c}}$ & $10 \pm 2.88^{\mathrm{d}}$ \\
\hline Dead \% & $12 \pm 1.15^{\mathrm{b}}$ & $54 \pm 1.73^{\mathrm{a}}$ & $52 \pm 1.44^{\mathrm{a}}$ & $55 \pm 2.21^{\mathrm{a}}$ \\
\hline $\begin{array}{l}\text { Abnormality \% } \\
\text { Major }\end{array}$ & $4 \pm 0.58^{\mathrm{c}}$ & $15 \pm 0.58^{\mathrm{b}}$ & $22 \pm 0.58^{\mathrm{a}}$ & $25 \pm 1.73^{\mathrm{a}}$ \\
\cline { 2 - 5 } Minor & $7 \pm 0.58^{\mathrm{c}}$ & $15 \pm 1.15^{\mathrm{b}}$ & $12 \pm 1.15^{\mathrm{b}}$ & $20 \pm 1.73^{\mathrm{a}}$ \\
\hline Acrosmal Defect & $5 \pm 0.58^{\mathrm{c}}$ & $16 \pm 0.58^{\mathrm{b}}$ & $16 \pm 1.73^{\mathrm{b}}$ & $21 \pm 2.88^{\mathrm{a}}$ \\
\hline
\end{tabular}

Figures with different superscripts $\mathrm{a}, \mathrm{b}, \mathrm{c}$ and $\mathrm{d}$ within row are significantly different at least $\mathrm{p}<0.01$ highly significant and $\mathrm{p} .<0.001$ severly significant. 


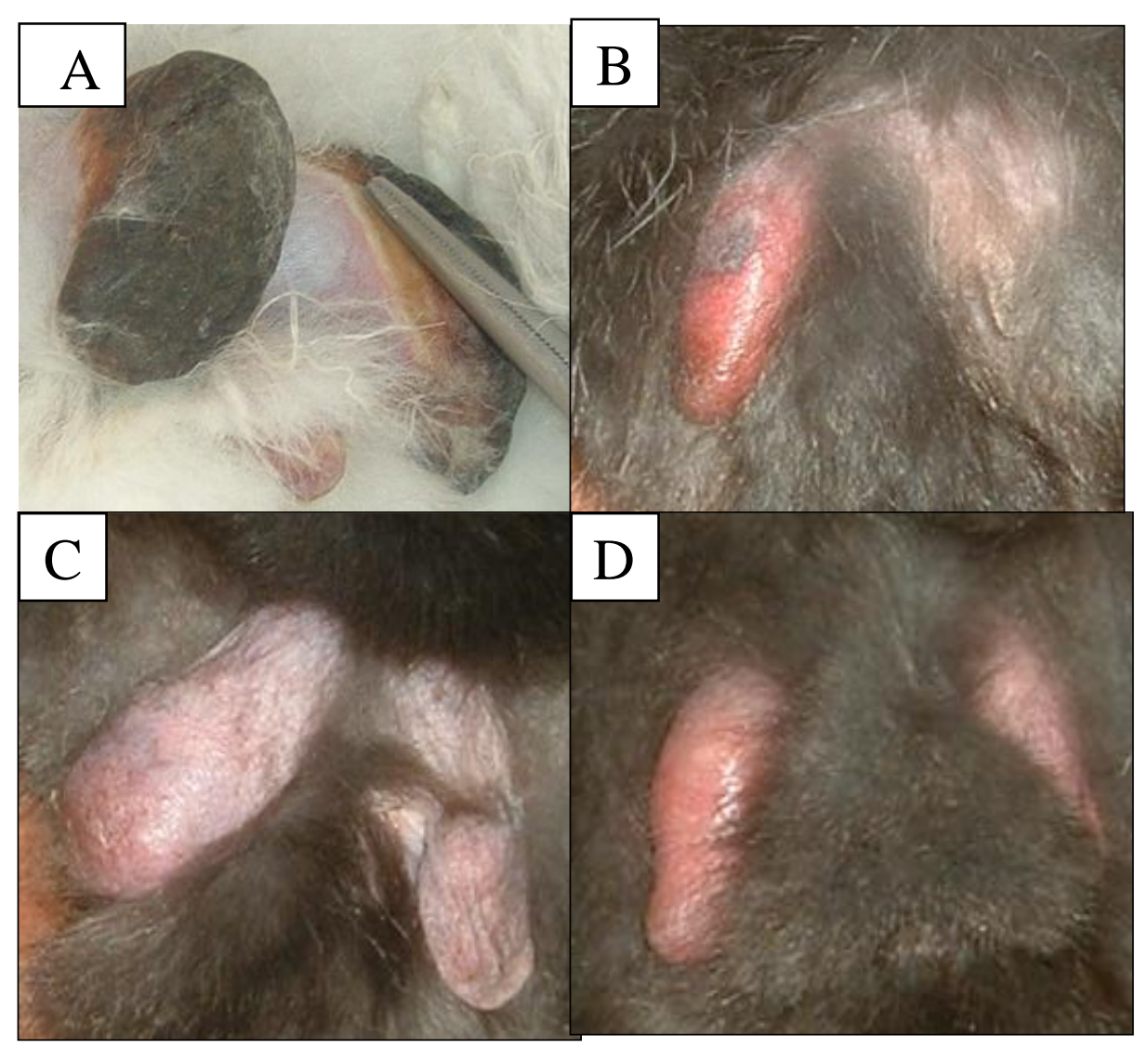

\section{Plate 1:}

A: Afield case buck testis infected with both Pasteurella multocida and Pseudomonas aeruginosa.

B: Experimental inoculated left testis with both Pasteurella multocida and Pseudomonas aeruginosa.

C: Experimental inoculated left testis with Pseudomonas aeruginosa.

D: Experimental inoculated left testis with Pasteurella. multocida. 


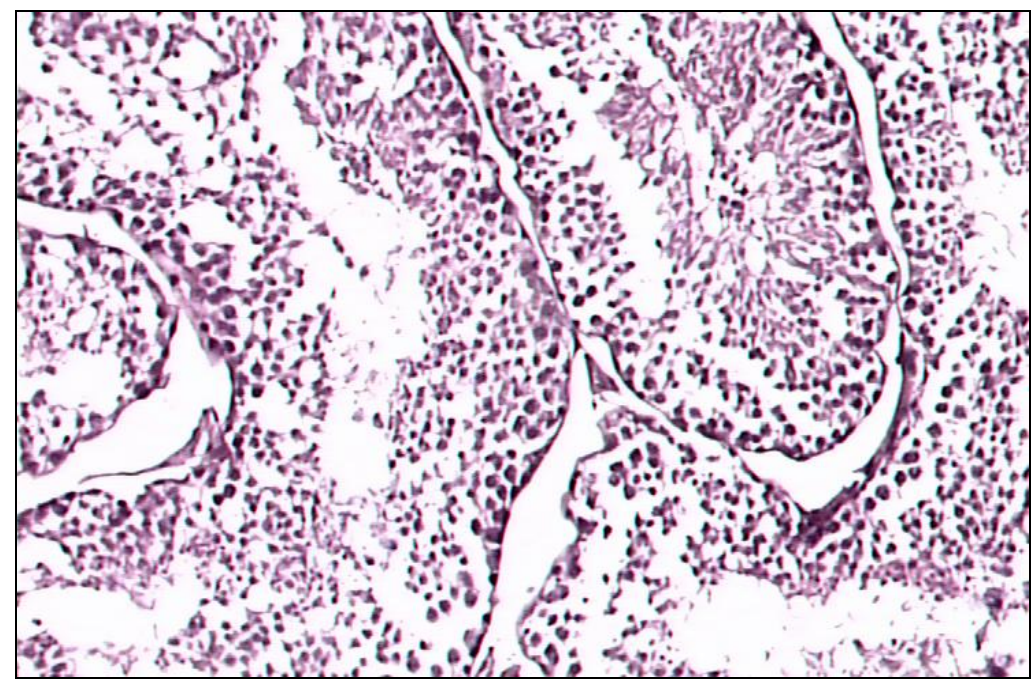

Fig. 1: Acute orchitis of rabbit experimentally inoculated (s/c) by Psudomonus aeruginosa showing intraluminal accumulation of desqumated spermatogoneal cells and sporadic heterophiles (H\&E, X100).

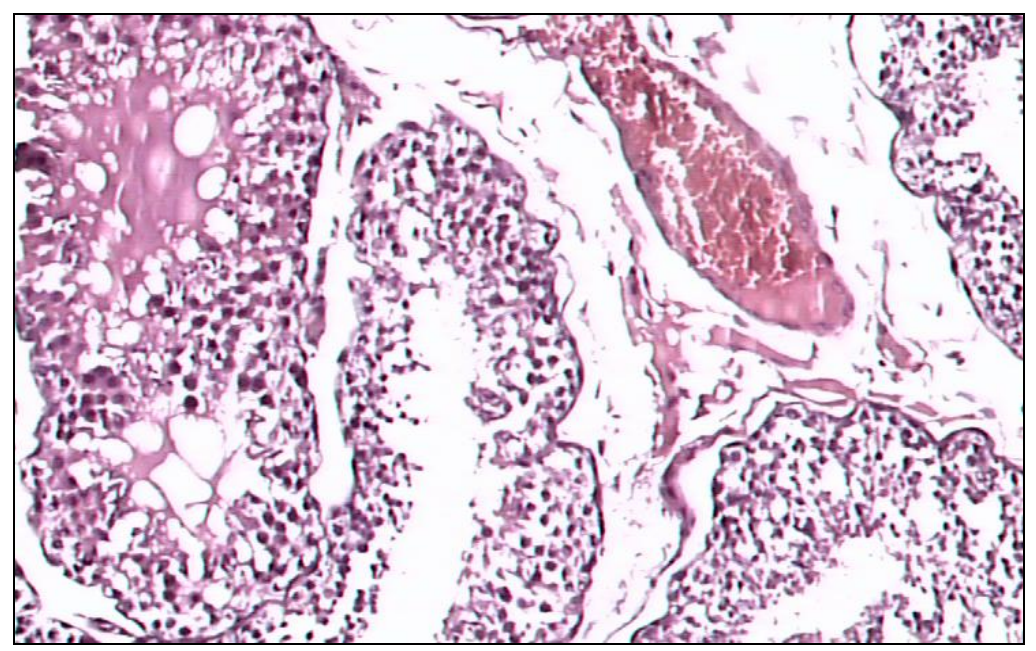

Fig. 2: Acute orchitis of rabbit experimentally inoculated (s/c) by Pasteurela multocida showing congested blood vesels, edema in the interstitial tissue and intraluminal accumulation of exudates consisting of mononuclear cells and desquamated spermatogoneal cells (H\&E, X100). 


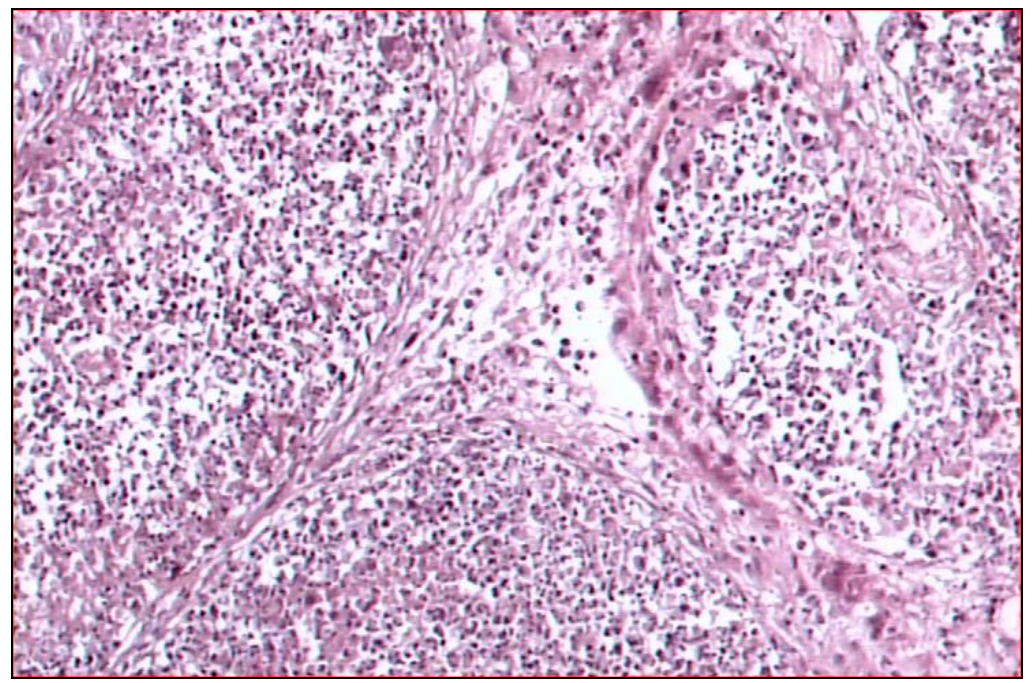

Fig. 3: Acute orchitis of rabbit experimentally inoculated (s/c) by both Psudomonus aeruginosa and Pasteurela multocida.showing thickening of the intertubular stroma with interstitial tissue infiltration by heterophiles and intraluminal accumulation of giant cells, necrotic cells and polymorphonuclear cells infiltration (H\&E,X100).

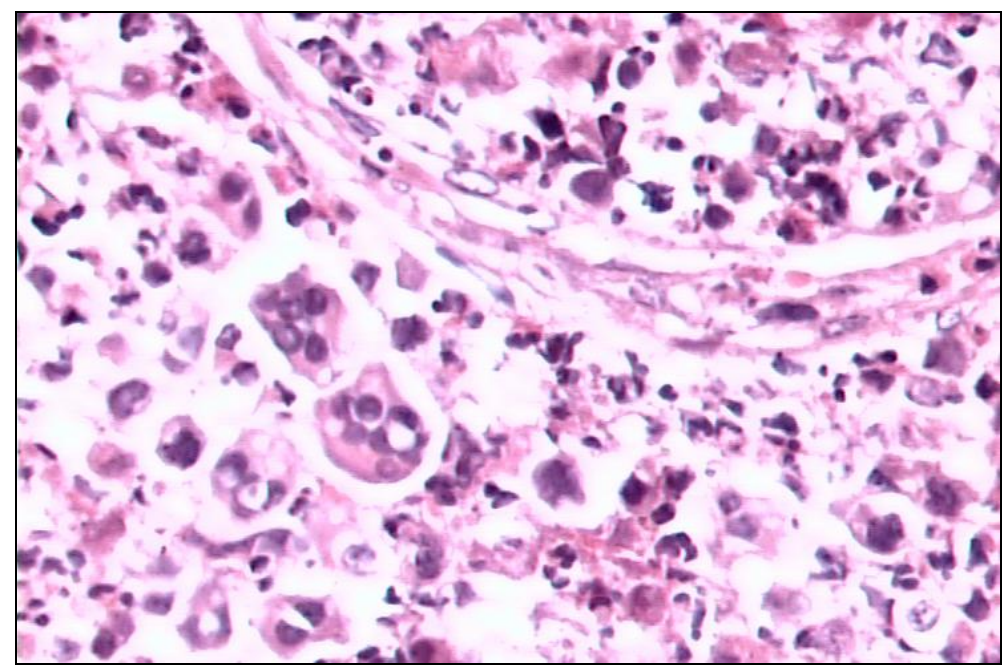

Fig. 4: High magnification of acute orchitis of rabbit experimentally inoculated (s/c) by both Psudomonus aeruginosa and Pasteurela multocida showing giant cells, necrotic cells and polymorphonuclear cells infiltration (H\&E, X400). 


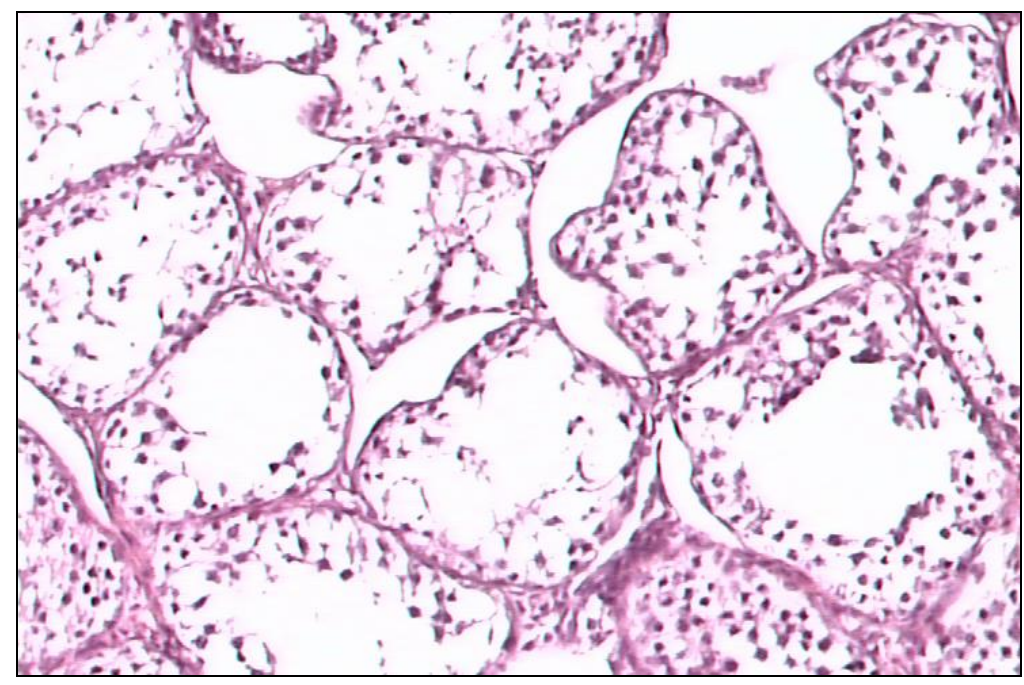

Fig. 5: Chronic orchitis of rabbit experimentally inoculated (s/c) by both Psudomonus aeruginosa and Pasteurela multocida showing depletion of spermatogoneal cells, and degenerated tubules (H\&E, X100).

The effect of the inoculated bacteria on cauda epididymal sperms is cleared in Table (1). After one week PI, the percentage of sperm motility was severly affected by the inoculated bacteria in all groups; values for infected groups differed significantly from control ( $p<0.001$ ) specially in third group, the motility decreased to $5 \%$ while control was $80 \%$. Also increased the percentage of dead sperms differed significantly from control ( $p<0.001$ ); the highest percentage of dead sperm was in third group (90\%) while control was (8\%). Major and minor sperm cell defects in all groups had a significant increase ( $p<0.001)$ from control; specially in third group, in which the major defect was $25 \%$ and minor defect was $40 \%$ while control was 10 and $3 \%$ respectively. In addition the percentage of acrosomal defects significantly increased in all groups ( $p<0.01$ ) from control and highest value of acrosomal defects was recorded with third group (19\%), while it was 3\% in control.

Concerning of semen characteristics in all infected groups at $4^{\text {th }}$ week P.I., summarized in Table (2), the volume of semen in control was normal mean 0.8 but after infection, values for infected groups differed significantly from control ( $\mathrm{p}<0.01$ ), the three groups were $0.5,0.3$, and $0.2 \mathrm{ml}$ respectively. All groups had low sperm concentration, which differed significantly from normal ( $p<0.001$ ). Mean of control sperm 
concentration was $273 \times 10^{6} / \mathrm{ml}$, while in the three infected groups were 196,82 , and $48 \times 10^{6} / \mathrm{ml}$. It was found that the severe decrease was in third group. Sperm motility of infected groups had differed significant ( $p<0.001$ ) from control. Third group was found to be significantly lower than first and second groups, $10 \%, 30 \%$ and $20 \%$ respectively, compared to control $(75 \%)$. Dead sperm in different groups was increased significantly ( $\mathrm{p}<0.001)$ differences from control. Mean values of three groups were $54 \%, 52 \%$ and $55 \%$ respectively, while control was $12 \%$. Major and minor defects in all groups significantly increased ( $\mathrm{p}<0.001)$ from control; major defects were $15 \%, 22 \%$ and $25 \%$ and minor defects were $15 \%, 12 \%$ and $20 \%$ in three groups respectively, while control major was $4 \%$ and control minor was $7 \%$. The highest percentage of major and minor defects recorded in third group. All infected groups had high acrosomal defects which differed significantly ( $p<0.001)$ from control. The highest value was recorded in third group (21\%), while second and first groups values were 16\% compared to control (5\%).

\section{Pathological results:}

\section{(A) Gross examination:}

The observed gross findings of the experimental groups started to appear 3 days P.I and onwards till the end of experiment as shown in plate (1). These findings were manifested as enlargement and congestion of the inoculated side. In first group, the scrotal reddish color changed to bluish after three days. The second group, smaller abscess was recorded $(\mathrm{s} / \mathrm{c})$ at the site of inoculation. The third group, the scrotum showed black necrotic areas at inoculation sites, that later get sloughed and became ulcers. The control was found to be normal, shape and size, while the clinical findings recorded in bucks examined at the end of experiment $\left(4^{\text {th }}\right.$ week $)$ started to relief in all group except in group one, the scrotum was enlarged and thickened.

\section{(B) Microscopical examination:}

\section{First group:}

At $1^{\text {st }}$ week from the inoculation with Pseudomonas aeruginosa, the lesions consisted of, mild congestion, intense edema and focal leucocytic cells infiltration of the tunics. Seminiferous tubules either showed desquamation of some spermatogoneal cells that appeared degenerated or showed necrobiotic changes. Intraluminal accumulation of desquamated cells, few heterophiles, and spermatozoa were observed (Fig.1). Mild hyalinizations of tubular basement membrane was also seen. In some areas tubules of the ductus epididymis were widely dilated 
and filled with cellular exudates and were separated by edematous intertubular stroma.

At $4^{\text {th }}$ week, the tunica albuginea appeared thick, seminiferous tubules showed depletion of germinal cells (some seminiferous tubules appeared with one to two layers of spermatogoneal cells). Tubules in few areas were either loss of the basement membrane or undergo necrotic changes in spermatogenic cells with intraluminal accumulation of vacuolated cells, few mononuclear cells and spermatozoa. Interstitial tissue infiltration with few mononuclear inflammatory cells was seen. The convoluted tubules of the ductus epididymis containing varying amounts of cellular exudates consisting chiefly of cell debris, immature spermatogoneal cells, spermatides and spermatozoa.

\section{Second group:}

At $1^{\text {st }}$ week from the last inoculation with Pasteurella multocida, consisted of severe congestion, mild to moderate edema and severe necrosis of the seminiferous tubules with intraluminal accumulation of exudates consisting of desquamated spermatogoneal cells and mononuclear cells (Fig.2). In some areas, the tubules were empty or contain some vacuolated spermatogoneal cells.

At $4^{\text {th }}$ week, the testicular parenchyma showed severe depletion of spermatogoneal cells in some seminiferous tubules that showed intraluminal accumulation of desquamated cells and cell debris and became atrophied. The tubules of ductus epididymis were dilated with interstitial edema. Some of the tubules surrounded by fibrous tissue and contain more folds.

\section{Third group:}

At $1^{\text {st }}$ week, the rabbit bucks infected with both Pseudomonas and Pasteurella, the lesions were much more intensive, the tunica albuginea appeared thick and edematous, moderate congestion and slightly infiltrated with heterophiles. Adjacent seminiferous tubules showed diffuse necrosis of the spermatogoneal cells, which were infiltrated with polymorphonuclear cells (heterophiles) and giant cells (Fig. 3, 4) and were separated by thickened intertubular stroma. The epididymis showed polymorphonuclear (heterophiles) cells infiltration in the interstitial tissue with extravastion of erythrocytes.

At $4^{\text {th }}$ week, lesions showed deplation of spermatogoneal cells of many seminiferous tubules and others degenerated tubules were noticed (Fig.5). The interstitial tissue showed slightly congestion, edema and mild leucocytic cells infiltration. Lesions of the epididymis were similar to those observed in Pseudomonas infection cases. 


\section{DISCUSSION}

This study was planned to clarify the bacterial agents in field cases of testicular lesions of rabbit bucks and investigate the effect of these agents on testes, on the cauda epididymis sperm and semen. The available literature revealed very scanty references dealing with the bacterial isolates from the rabbit male sex organs. Mercier and Rideaud (1990) isolated Corynebacterium, Staphylococcus aureus and Proteus mirabilis from the semen of rabbits. Riad (2000) isolated Corynebacterium, Staphylococcus aureus and Pseudomonas aeruginosa from semen and testes of bucks. Nearly similar bacterial isolates could be recovered from the sex organs and semen of other animals other than rabbits including bulls, cows, buffalo bulls, sheep and swine (Wierzbowski et al., 1980; Hassan, 1991 and Saweris, 1996), Wierzbowski et al., 1980 noticed that these bacterial isolates had toxic effect on the spermatozoa. In the present study Pasteurella multocida and Pseudomonas aeruginosa were the only bacteria isolated from testes of the field cases in a farm suffering from infertility problem, whereas Pseudomonas aeruginosa only was isolated from the prepuce. The bacteriological examination of samples obtained from the inoculated rabbits revealed the isolation of these organisms from testes and semen.

In the experimental study, a strain of Pseudomonas and a strain of Pasteurella isolates were inoculated subcutaneous(s/c) route of testes singly in two separated groups or both in the third group. Although the intra -testicular route adopted by See et al. (1990) and Riad (2000).

Lekili et al. (1992) had not recommend this route and stated that it is rarely simulates the field natural infection. Therefore choosing the subcutaneous $(\mathrm{s} / \mathrm{c})$ route inoculation was done because in nature mature rabbits bucks may bite each other at scrotal skin during their fighting, also traumatic wounds from cages and during transportation usually occur at this area, this was supported by Richardson (2000). The infection from the outside environment facilitate the entrance of such pathogenic organisms indirectly to the testes, this also avoided the expected general septicaemia which might occur and mask the lesions in the examined target organs.

Kahn (2005) reported that the subcutaneous and visceral diseases caused by Pasteurella may be clinically concealed for long period and spontaneously rupture when bucks fight together, their wound frequently develop abscess, in this concept he added that pasteurllosis presents with a variety of clinical symptoms including abscesses, reproductive tract 
infections and snuffles induced primarily by Pasteurella but Pseudomonas, Staphylococcus and Streptococcus have also been isolated. Riad (2000) found that Pseudomonas aeruginosa had adverse effect on testes and semen quality.

Gross pathological findings appeared in the inoculated rabbit bucks were manifested by acute orchitis from third day P.I. until one week, which changed to chronic in nature at $4^{\text {th }}$ week P.I. These findings are similar with that observed in the field cases (Plate 1). The experimental s/c infection of rabbit bucks with Pseudomonas aeruginosa and Pasteurella multocida either single or both, resulted in moderate to severe scrotal inflammation which lead to damage of the testicular parenchyma with different degrees of the severity, this come in accordance with Helen (1995) who reported that inflammation of the scrotal skin can injure the testis. From Table $(1,2)$, we found that, both infections with Pasteurella and Pseudomonas had worse effects than Pseudomonas and Pasteurella individually on spermatozoa. Buck doesn't loose sexual desire but incomplete matting done in acute period due to presence of signs of inflammation (swelling and painful, etc.), so it is difficult to collect the semen at $1^{\text {st }}$ week.After acute inflammatory signs disappeared, bucks were able to ejaculate and semen could be collected. The bacterial toxic effect lead to inflammatory harmful changes which caused severe damage to the testicular and epididymal functions and consequently lead to reduction in volume, cell concentration, a live sperm $\%$ and sperm motility $\%$ and increased sperm abnormality and acrosomal defect \%. Dead sperm has been found to be negatively correlated with fertility (AbdEL-Ghaffar, 1992). Also Castellini and Lattaioli (1999) and Yousef et al. (2001) found that bucks sperm numbers and number of motile sperms are positively associated with both fertilization and embryo numbers. Romaniuk (1965) concluded that, when the total viable bacterial count exceeded $3 \times 10^{5}$ viable microorganisms/ $\mathrm{ml}$, it adversely affected fertility. Histopathological examination revealed that, the recorded lesions in the testis at $1^{\text {st }}$ and/or $4^{\text {th }}$ week following infection with both Pseudomonas aeruginosa and Pasteurella multocida were more local intense than those infected with either Pasteurella multocida or Pseudomonas aeruginosa alone. The seminiferous tubules showed sever necrosis of the spermatogoneal cells and progressive to complete depletion of spermatogoneal cells. Helen (1995) stated that the losses of germinal cells are indicating the severity of testicular degeneration. The more 
extensive histopathological lesions observed support the obtained results of sperms \&semen evaluation recorded in the Tables $(1,2)$.

Obtained results of histopathology following infection with Pseudomonas aeruginosa were in accordance but with less intense than that observed by Lucchetta et al. (1983); See et al. (1990) and Rowida (2000) in experimental E.coli and Pseudomonas aeruginosa infection of rat and bucks via intra-testicular inoculation. They recorded testicular inflammation with peritubular infiltration of leucocytes accompanied with seminiferous tubules necrosis. Most of the lesions reported at the end of experiment $\left(4^{\text {th }}\right.$ week) were irreversible and has deleterious effect on fertility of bucks except Pseudomonas aeruginosa infection alone which affect more on the scrotum.

Kahn (2005) advises to eliminate rather than treat in cases of such infection in a rabbitry. The contaminated hutch and its equipments should be carefully disinfected. Non of the Pasteurellae is specially resistant to adverse agents or environmental conditions, the organism is killed at $55^{\circ} \mathrm{C}$ and by $0.5 \%$ phenol within 15 min. (Collier et al., 1998).

\section{Conclusions and recommendations:}

Pasteurella multocida induces worse effect on semen characteristics than Pseudomonas aeruginosa, while mixed infection with both bacteria have the most adverse effect than every microbe alone. Buck does not loose sexual desire but incomplete matting done in acute period. In chronic infection bucks had infected semen be able to complete matting and cause not only less number of litters and infertility, as recorded in naturally infected cases due to poor semen, but also spread of infection to does with subsequent bad effect on reproduction. Therefore, attention should be paid to any complain from infertility in any rabbitry for semen evaluation and bacteriological examination and rapid treatment of any wound in rabbit before complications.

\section{REFERENCES}

Abd EL-Ghaffar, N.EL-S (1992): Some studies on the artificial insemination in rabbit. Ph.D. Thesis, Faculty of Vet. Med. Zagazig Univ. (Banha).

Bancroft, J.D. and Stevens, A. (1990): Theory and practice of histological techniques. Third edition, New York.

Blom, E. (1977): Sperm morphology with reference to bull infertility. First A11-India symp. Anim. Reprod., Ludhiana. 
Castellini, C. and Lattaioli, P. (1999): Effect of number motile sperms inseminated on reproductive performance of rabbit does. Anim. Rep. Sci. 57 (1-2): 111-120.

Collier, L.; Albert, B. and Sussman, M. (1998): Topley and Wilson's Microbiology and Microbial infections. $9^{\text {th }}$. ed. Vol.2 Oxford Univ. Press. Inc., New York.

Cruickshank, R.; Duguid, J.P.; Marmion, B.P. and Swain, R.H.A. (1975): Medical Microbiology, $12^{\text {th }}$ ed. Vol. II, Churchill Livingstone, Edinburgh, London and New York.

Evans, G. and Maxwell, W.M.C. (1987): Salmons artificial insemination of sheep and goats. Buterwarths pty limited, Australia.

Finegold, S.M. and Baron, E.J. (1986): Baily and Scott ${ }^{\mathrm{s}} \mathrm{s}$ Diagnostic Microbiology. $7^{\text {th }}$ Ed. The C.V. Mosby Co. St. Louis. Toronto.

Hassan, A.M.M. (1991): Investigation of the interaction among bacteria, antibiotics and spermatozoa in fresh frozen buffalo and friesian bull semen. Ph. D Thesis, Fac. of Vet. Med., Cairo Univ.

Helen, M. Acland (1995): Thomson's Special Vet. Path. $2^{\text {nd }} . e d$, Published by MERK\& Co.INC, USA.

Jaglic, Z.; Jeklova, E.; Leva, L.; Kummer, V.; Kucerova, Z.; Faldyina, M.; Maskova, J.; Nedbalocova, K. and Alexa, P. (2008): Experimental study of Pathogenicity Pasteurella multocida serogroup F in rabbits. Vet. Microbiol. 1, 126 (1-3): 168-177.

Kahn, C.M. (2005): The Merk Veterinary Manual, $9^{\text {Th }}$ ed. Published by MERK \& Co. INC, USA.

Lekili, M.; Tekgul, S.; Ergen, A.; Tasar, C. and Hascelik (1992): Acute experimental unilateral orchitis in the rabbit and its effect on fertility International Urology and Nephrology 24(3), 291-297.

Lucchetta, R.; Clavert, A.; Meyer, J.M. and Bollack, C. (1983): Acute experimental E-coli epididymitis in the rat and its consequences on spermatogenesis. Urological Research, 11:117-120.

Mercier, P. and Rideaud, P. (1990): Bacteriology of fresh rabbit semen. Preliminary study. INRA Production Animals, 3(3), 215-221.

Nada, H.S. (1994): Pasteurella multocida isolated in rabbits: serologic types and experimental infection. Vet. Med. J., Giza. 42(3): 73-77.

Reynolds, A.; Thomas, T.; Wilson, W. and Oliphant, G. (1989): Concentration of Acrosome Stabilizing Factor (ASF) in rabbit epididymal fluid and species specificity of Anti- ASF. Antibodies. Biol. of Reprod. 40, 673-680. 
Riad Rowida, R.M. (2000): Effect of seminal bacterial pathogens on rabbit bucks performance Ph.D. Faculty of V.Med. Cairo University.

Richardson, V.C.G. (2000): Rabbits health, Husbandry and Diseases. Blackwell Sience Ltd. Oxford, London.

Romaniuk, J. (1965): The influence of seminal flora on the bull semen. Medycyna Wet. 21: 424-427.

Saweris, Y.S.S. (1996): Microbiological studies on corynebacterium ovis in sheep and goat. M.V.Sc. Thesis, Fac. Vet.Med., Cairo Univ.

See, W.A.; Taylor, T.O.; Mack, L.A.; Tarataglione, T.A.; Opheim, K.E. and Berger, R.E. (1990): Bacterial epididymis in the rat: Amodel for assessing the impact of acute inflammation on the epididymal antibiotic penetration.J.Urol., 114(3), 780-784.

SAS (1990): SAS/STAT User's Guide (vertion6, $4^{\text {th }}$ ed.) SAS Inst. Inc., Caly, NC.

Snedecor, G.H. and Cochran, W.G. (1982): Statistical Methods. $2^{\text {nd }}$ Ed. Iowa Univ. Press. Ames, Iowa.

Wierzbowski, S.W.; Nowakowski, W.; Fueowiez, A. and Heezko, P. (1980): Biochemical and toxic of potentially pathogenic microorganisms isolated from bull semen. $9^{\text {th }}$ International Congress of Animal Reproduction and Artificial Insemination, Madrid, Spain, 725-732.

Yousef, M.I.; Zeitoun, M.M.; Abaza, M.M. and EL-Raffa, A. (2001): Total motile sperm autput as combining parameter for fertility predication in rabbits. Egy. Soci. for animal reproduction and fertility, Thirteenth Annual Congress, p:205. 
Assiut Vet. Med. J. Vol. 54 No. 119 October 2008

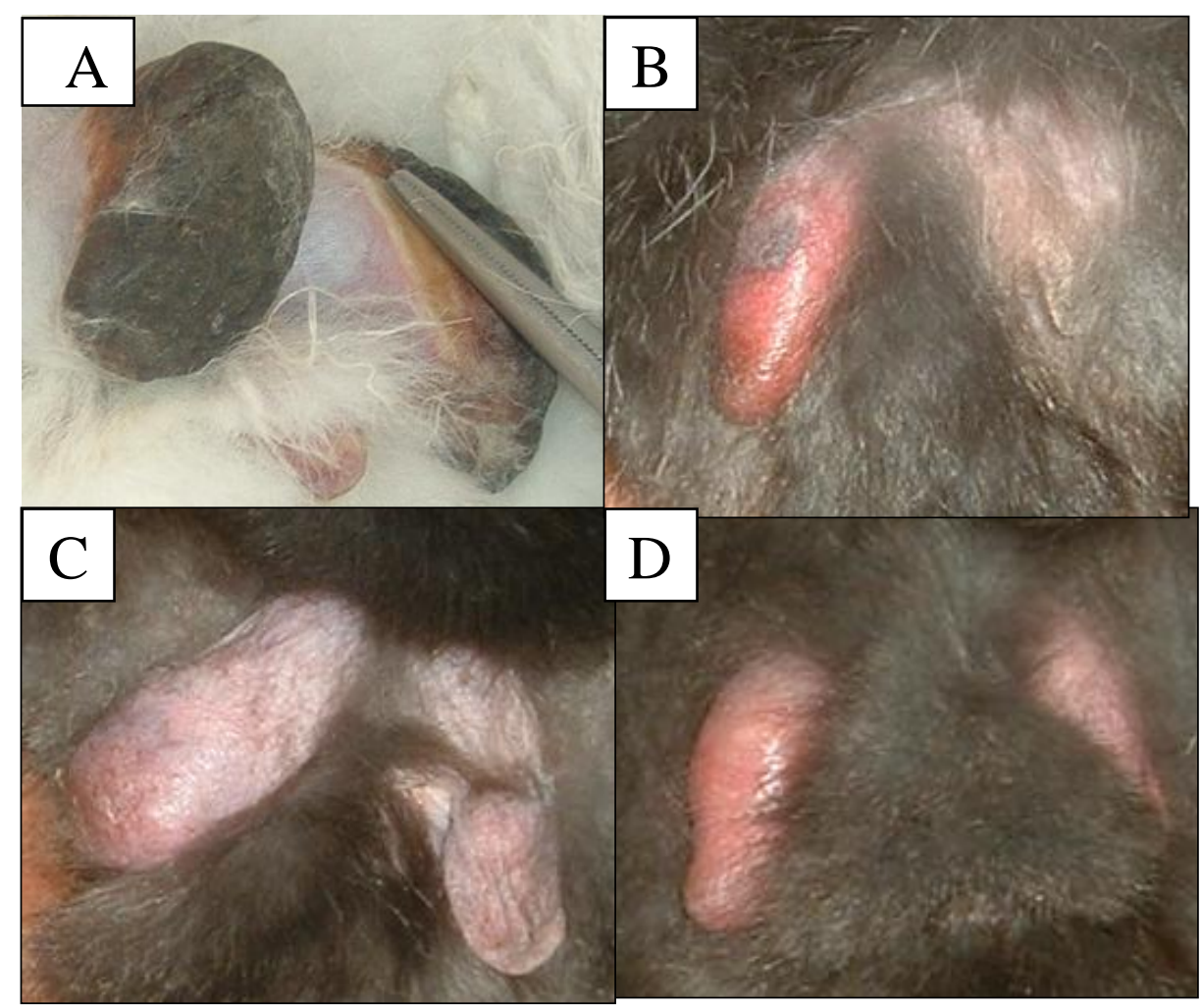




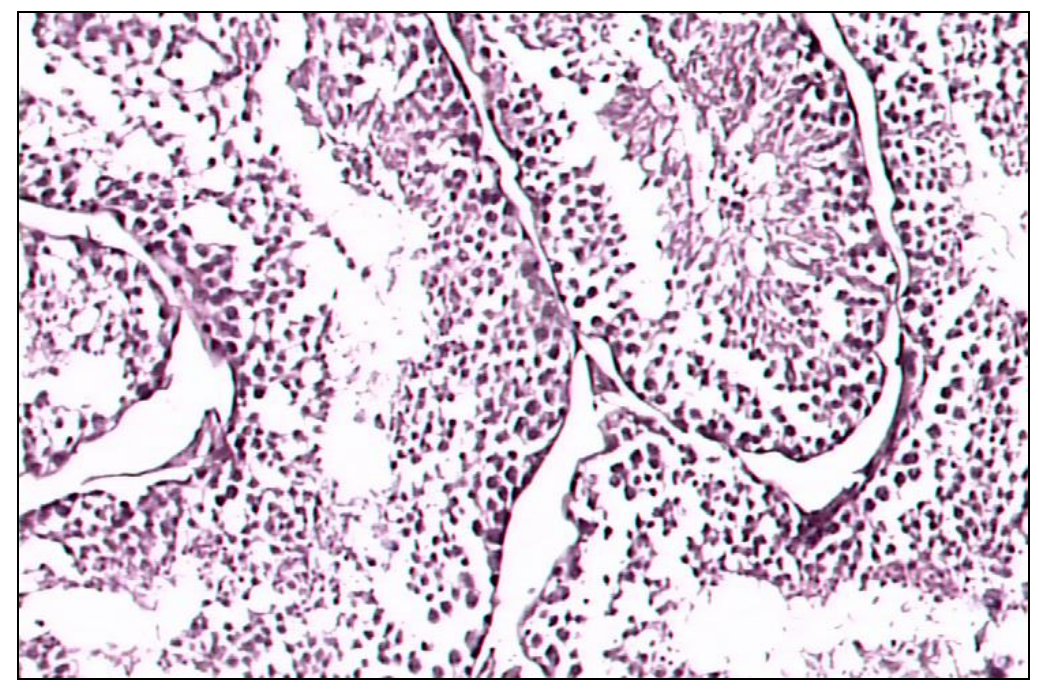


Assiut Vet. Med. J. Vol. 54 No. 119 October 2008

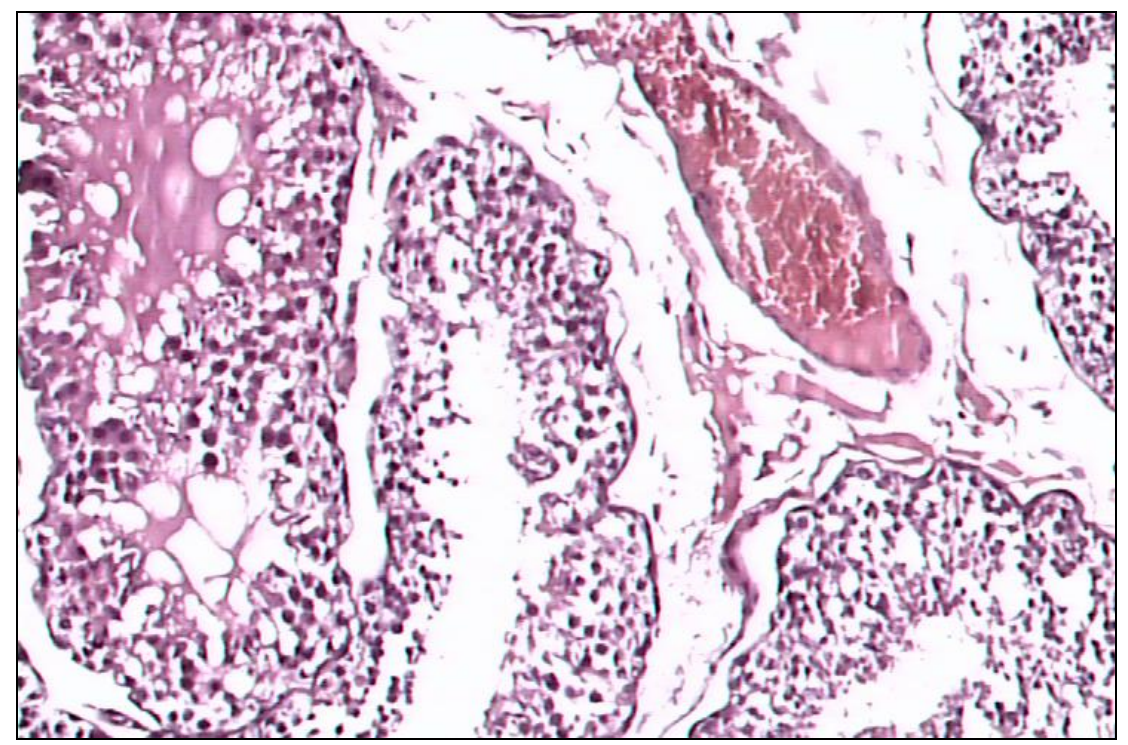


Assiut Vet. Med. J. Vol. 54 No. 119 October 2008

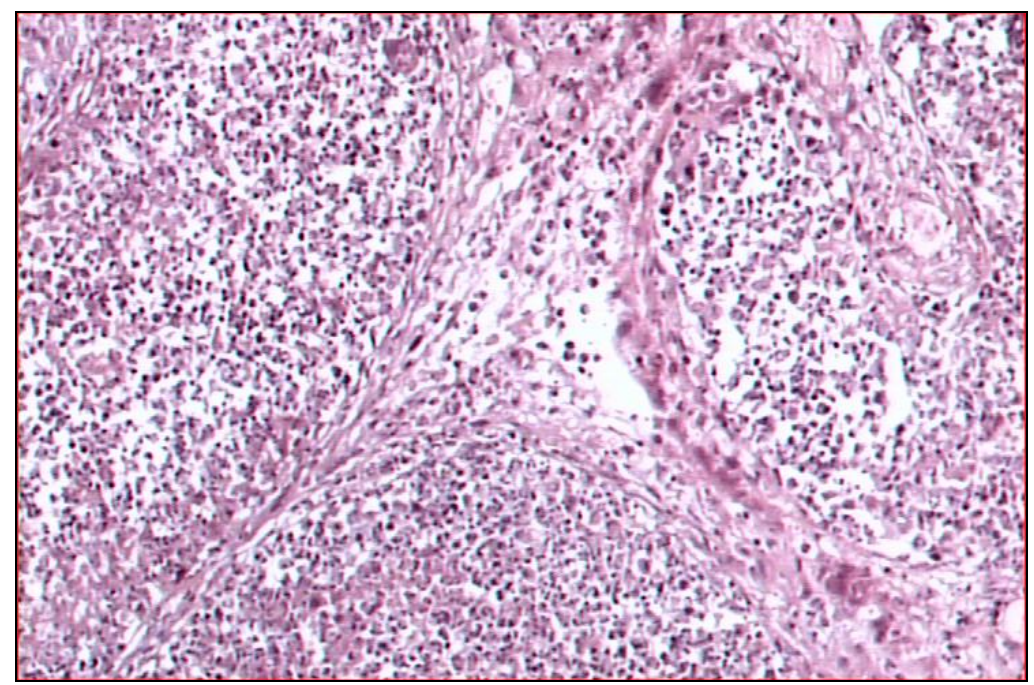


Assiut Vet. Med. J. Vol. 54 No. 119 October 2008

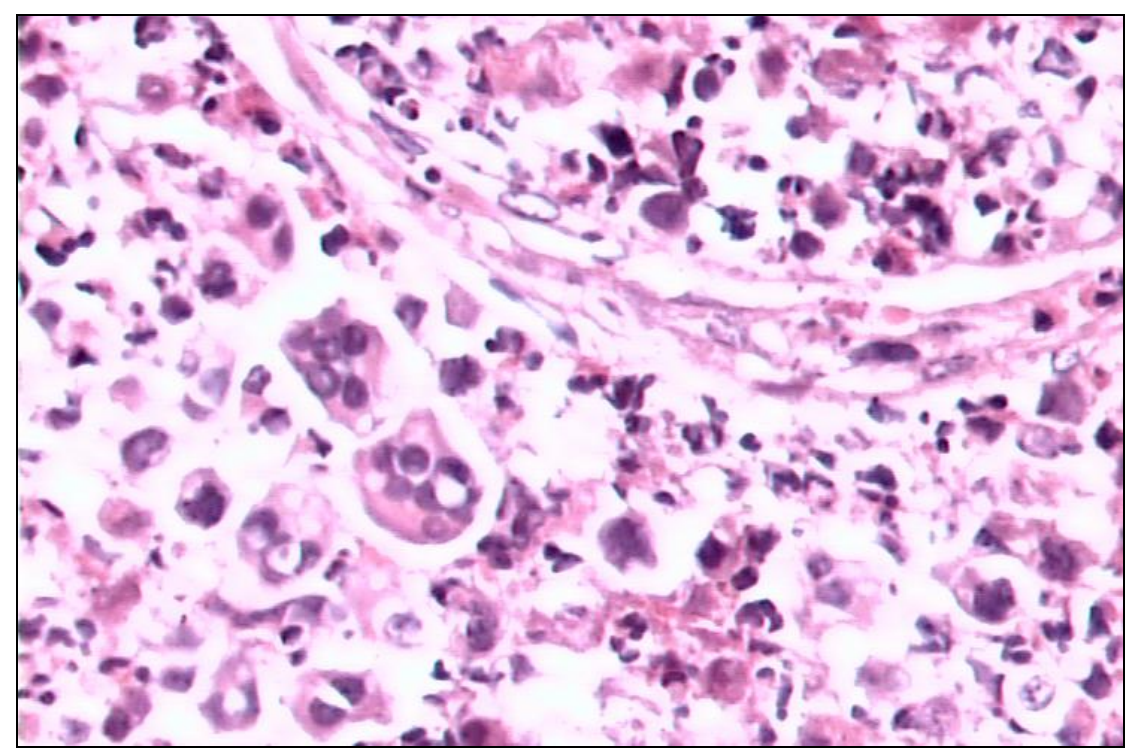


Assiut Vet. Med. J. Vol. 54 No. 119 October 2008

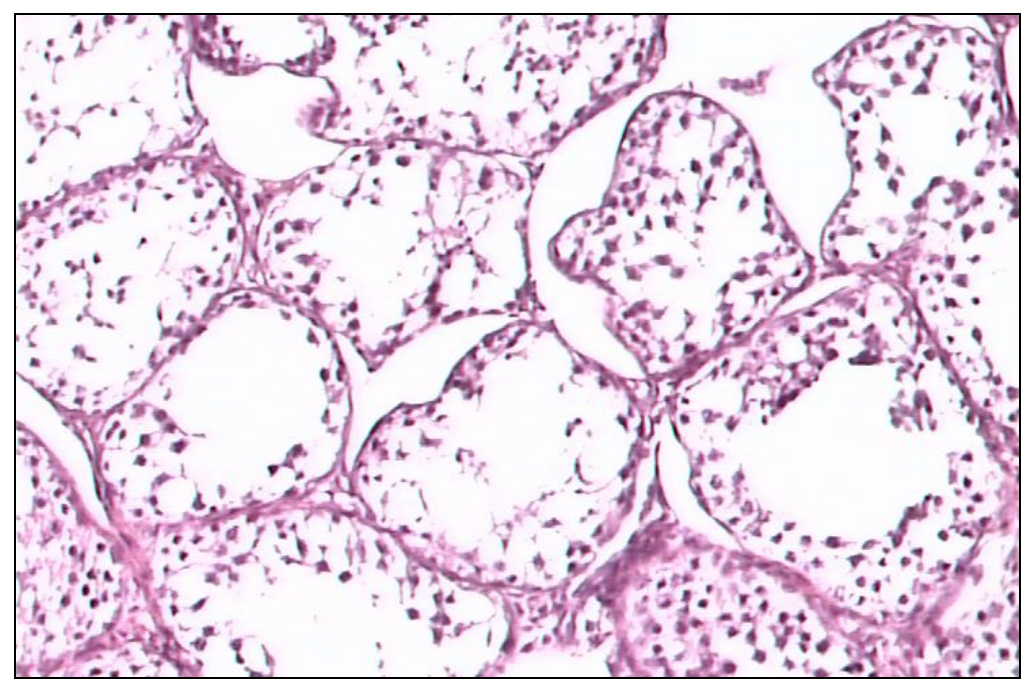

